\title{
Sugar Transport and Fructose Metabolism in Human Intestine In Vitro *
}

\author{
Lawrence W. White and Bernard R. Landau $\dagger$ \\ (From the Departments of Medicine and Biochemistry, Western Reserve University, \\ Cleveland, Ohio)
}

Present knowledge regarding sugar transport by human intestine has been derived primarily by extrapolation of data from other species. Previous investigations, performed chiefly with everted sacs of hamster intestine, show that a sugar requires a specific structure before it can be transported by intestine against a concentration gradient, a process referred to as "active transport" $(1,2)$. Thus, in the hamster, the necessary requirements for a monosaccharide to be actively transported are a pyranose ring, a $\mathrm{D}$-configuration, a hydroxyl group in the glucose configuration at carbon 2, and a methyl or substituted methyl group at carbon 5. Sugars that lack one of these features, or possess a large substituent on some part of their structure, are not actively transported. Fructose, lacking these requirements, is therefore not transported against a gradient. Nonetheless, fructose disappears from the rat intestinal lumen at a rate intermediate between that for sugars such as glucose or galactose, which are actively transported, and sugars such as mannose or pentoses, which are not (3). Since passive diffusion of a sugar through the intestinal wall is dependent upon the difference between its intracellular and extracellular concentration (2), the enhanced rate of fructose disappearance as compared to mannose or pentoses may be accounted

\footnotetext{
* Submitted for publication January 8,1965 ; accepted March 18, 1965.

Supported by grants from the National Institute of Arthritis and Metabolic Diseases (AM-06810), the American Heart Association, and the Lee Fund of Western Reserve University for the Study of Diabetes and Related Diseases.

† Address requests for reprints to Dr. Bernard $R$. Landau, Dept. of Medicine, Western Reserve University School of Medicine, Cleveland, Ohio 44106.

This study was performed during the tenure of an Established Investigatorship of the American Heart Association.
}

for by its partial conversion to another substance, such as lactate (4) or glucose (4-8).

Conversion of fructose to glucose by the intestine was first suggested by Bollman and Mann (5) and since then has been demonstrated in the guinea pig $(4,6)$, hamster $(7)$, rat $(4)$, and dog (8). Conversion of fructose to glucose by human intestine has been assumed, but never established. Miller, Craig, Drucker, and Woodward (9), in a patient with cirrhosis of the liver given fructose orally, observed a greater glucose concentration in portal anastomotic vein blood than femoral arterial blood, by $5 \mathrm{mg}$ per $100 \mathrm{ml}$, suggesting a conversion of fructose to glucose. Their observation that oral fructose administration produced effects other than those of parenteral fructose supported the possibility of intestinal conversion, but different rates and sites of initial presentation could explain this finding.

The mechanism of conversion of fructose to glucose in animals has been examined. The possible pathways are outlined in Figure 1. Fructose can either be converted to glucose via initial phosphorylation to fructose-1-phosphate, catalyzed by fructokinase, or to fructose-6-phosphate, catalyzed by hexokinase. Kjerulf-Jensen (10) isolated fructose-1-phosphate from guinea pig intestine and suggested that it was an intermediate in fructose absorption. Subsequent reactions in the metabolism of fructose-1-phosphate are cleavage to dihydroxyacetone phosphate and glyceraldehyde, isomerization of the dihydroxyacetone phosphate to glyceraldehyde phosphate, phosphorylation of the glyceraldehyde, condensation of triose phosphates to form fructose-6-phosphate via fructose-1,6-diphosphate, isomerization to glucose-6-phosphate, and hydrolysis to free glucose by the action of glucose-6-phosphatase. Figure 1 traces the pathway followed by carbon 1 of fructose-1-C $C^{14}$. If metabolism is via fructose-1-phos- 


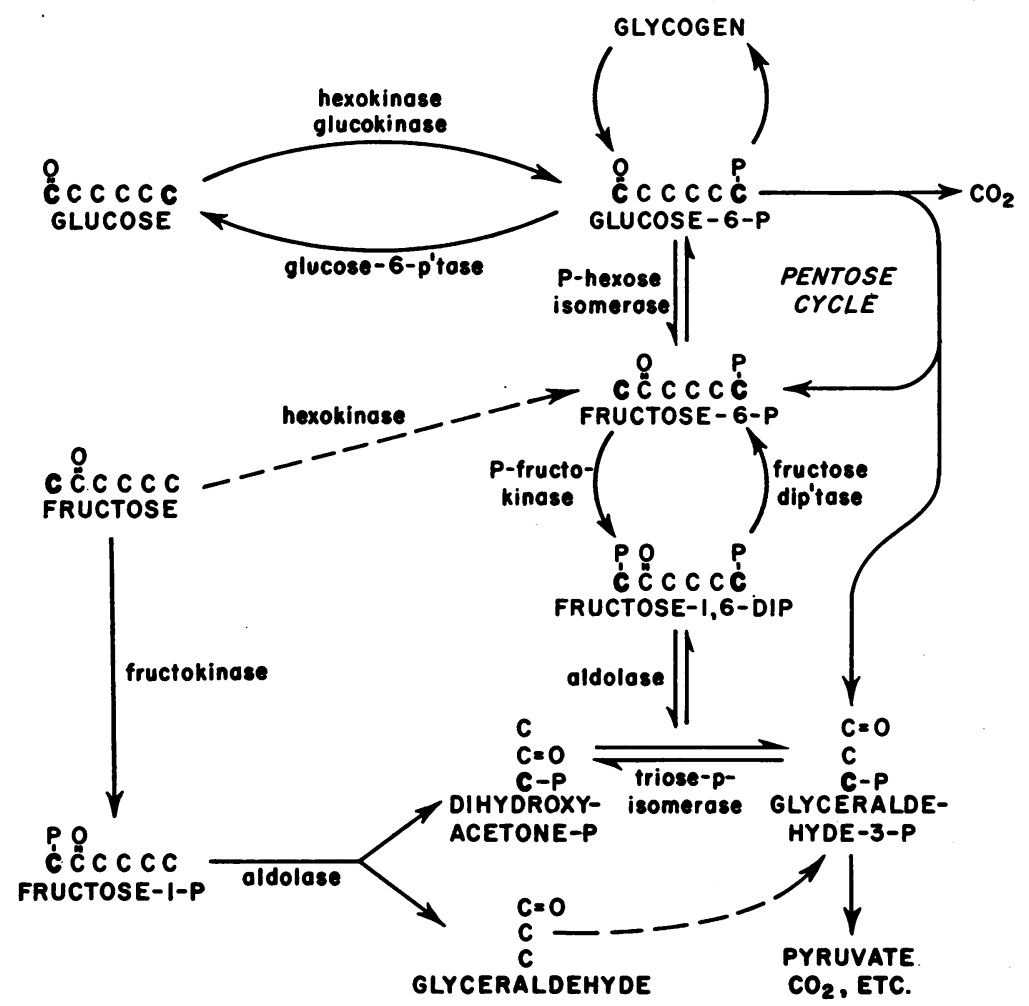

Fig. 1. Conversion of Fructose to GLucose. The labeling pattern of intermediates is for the metabolism of fructose-1- $\mathrm{C}^{\mathbf{1 4}}$ via fructose-1-phosphate, where $\mathrm{C}^{\mathbf{1 4}}$ is traced by boldface type.

phate, glucose-1,6-C ${ }^{14}$ is formed. Via fructose-6phosphate, glucose-1-C ${ }^{14}$ would be expected. Ginsberg and Hers (11) and Salomon and Johnson (12) provided good evidence for conversion via fructose-1-phosphate by isolating glucose-1,6$\mathrm{C}^{14}$ after incubation of intestine from guinea pig with fructose-1- $\mathrm{C}^{\mathbf{1 4}}$ or fructose-6- $\mathrm{C}^{\mathbf{1 4}}$.

To form glucose from fructose, an essential reaction is the hydrolysis of glucose-6-phosphate to glucose. The failure to demonstrate glucose-6phosphatase in rat intestine presumably accounts for the inability of rat intestine to convert fructose to glucose (11), although a recent abstract reports the presence of glucose-6-phosphatase activity in rat mucosa, accompanied by an endogenous inhibitor preventing its action (13). This contrasts with the demonstration in the guinea pig of a preferential hydrolysis of glucose-6-phosphate as compared with glucose-1-phosphate, consistent with the conversion of fructose to glucose (11). In a single study on human intestine, no glucose6-phosphatase activity was found (11). How- ever, other groups have recently demonstrated glucose-6-phosphatase activity in human intestine $(14,15)$. In the present communication, in vitro techniques have been applied to the study of sugar transport and fructose metabolism in human intestine.

\section{Methods}

Source of tissue. Studies were performed on human intestine removed at the time of surgery. The source of tissue and the pathological diagnoses are outlined in Table I. Areas adjacent to the resection site, grossly free of pathological processes, were used. The mucosa was quickly dissected from the other layers, cut into strips, weighed, and incubated with appropriate solutions as outlined below. The time from surgical removal to the beginning of incubation was 15 to $30 \mathrm{~min}$ utes, during which period the tissue was kept cold. Histological examination of unincubated tissues verified the adequacy of the dissections. Mucosa was normal in all tissues except that in one area of the sample of tissue no. 4, a small ulcer was seen.

Sugar specificity. To determine the structural requirements for active transport, the ability of a tissue to accumulate monosaccharides of different structures 
TABLE I

Source of intestinal mucosa

\begin{tabular}{|c|c|c|c|c|}
\hline Tissues & Clinical features & $\begin{array}{l}\text { Site of tissue } \\
\text { excised }\end{array}$ & Surgery employed & Pathological diagnosis \\
\hline 1 & $\begin{array}{l}\text { Abdominal } \\
\text { pain, rectal } \\
\text { bleeding, mass }\end{array}$ & $\begin{array}{l}\text { High } \\
\text { jejunum }\end{array}$ & $\begin{array}{l}\text { Resection } \\
\text { of jejunum }\end{array}$ & $\begin{array}{l}\text { Lymphosarcoma } \\
\text { with focal ulcer- } \\
\text { ation and acute } \\
\text { inflammation } \\
\text { of small in- } \\
\text { testine }\end{array}$ \\
\hline 2 & $\begin{array}{l}\text { Diarrhea, } \\
\text { weight loss }\end{array}$ & $\begin{array}{l}\text { Terminal } \\
\text { ileum }\end{array}$ & $\begin{array}{l}\text { Total colec- } \\
\text { tomy and } \\
\text { ileostomy }\end{array}$ & $\begin{array}{l}\text { Acute ulcer- } \\
\text { ative entero- } \\
\text { colitis }\end{array}$ \\
\hline 3 & Rectal bleeding & $\begin{array}{l}\text { High } \\
\text { jejunum }\end{array}$ & $\begin{array}{l}\text { Resection } \\
\text { of jejunum }\end{array}$ & $\begin{array}{l}\text { Leiomyoma of } \\
\text { small intestine }\end{array}$ \\
\hline 4 & $\begin{array}{l}\text { Diarrhea, } \\
\text { weight loss, } \\
\text { debility }\end{array}$ & $\begin{array}{l}\text { Terminal } \\
\text { ileum }\end{array}$ & $\begin{array}{l}\text { Resection of } \\
\text { terminal ileum } \\
\text { and ascending } \\
\text { colon }\end{array}$ & $\begin{array}{l}\text { Regional } \\
\text { enteritis }\end{array}$ \\
\hline 5 & $\begin{array}{l}\text { Melena, insidi- } \\
\text { ous development } \\
\text { of anemia }\end{array}$ & $\begin{array}{l}\text { Middle } \\
\text { jejunum }\end{array}$ & $\begin{array}{l}\text { Resection of } \\
\text { jejunum }\end{array}$ & $\begin{array}{l}\text { Adenomatous } \\
\text { polyp of jejunum }\end{array}$ \\
\hline 6 & $\begin{array}{l}\text { Abdominal pain, } \\
\text { rectal bleeding, } \\
\text { mass }\end{array}$ & $\begin{array}{l}\text { High } \\
\text { jejunum }\end{array}$ & $\begin{array}{l}\text { Resection of } \\
\text { jejunum }\end{array}$ & $\begin{array}{l}\text { Fibromyoma } \\
\text { of jejunum }\end{array}$ \\
\hline 7 & $\begin{array}{l}\text { Abdominal pain, } \\
\text { obstructive } \\
\text { jaundice }\end{array}$ & Duodenum & $\begin{array}{l}\text { Resection of } \\
\text { duodenal } \\
\text { tumor }\end{array}$ & $\begin{array}{l}\text { Malignant } \\
\text { carcinoid } \\
\text { tumor }\end{array}$ \\
\hline 8 & $\begin{array}{l}\text { Abdominal pain, } \\
\text { intractable } \\
\text { diarrhea }\end{array}$ & $\begin{array}{l}\text { Terminal } \\
\text { ileum }\end{array}$ & Ileocolectomy & Regional enteritis \\
\hline
\end{tabular}

against a concentration gradient was examined (16). Segments of mucosa weighing 0.8 to $1.2 \mathrm{~g}$ were added to flasks containing one of several monosaccharides in $3 \mathrm{ml}$ of Krebs-Ringer bicarbonate buffer modified to a 1.3 $\mathrm{mM} \mathrm{Ca}{ }^{++}$concentration. The sugars were $\alpha$-methyl-Dglucose-U-C ${ }^{14}$, prepared as previously described (17), D-xylose-1-C ${ }^{14}$, and D-galactose-2- $C^{14} ;{ }^{1}$ D-fructose-U-C ${ }^{14} ;{ }^{2}$ D-mannose-U-C ${ }^{14} ;{ }^{8}$ 3-O-methyl-C $C^{14}-\mathrm{D}$-glucose ; 4 and 6deoxy-D-glucose, prepared as previously described (18). Incubation was performed at $37^{\circ} \mathrm{C}$ with shaking for 30 minutes under an atmosphere of $95 \% \quad \mathrm{O}_{2}$ and $5 \% \quad \mathrm{CO}_{2}$. After incubation, the segments were removed from each flask, blotted, and homogenized in $4 \mathrm{ml}$ of cold water. Samples of initial and final media and tissue homogenate were deproteinized with $\mathrm{Ba}(\mathrm{OH})_{2}-\mathrm{ZnSO}_{4}$ (19), and the supernatants were used for determination of $\mathrm{C}^{14}$ activity where the sugar was labeled and in some cases for measurement of sugar content. Tissue water was determined by the difference in tissue weight before and after

1 Purchased from the National Bureau of Standards, Washington, D. C.

2 New England Nuclear Corp., Boston, Mass.

${ }^{3}$ Schwarz Laboratories, Mount Vernon, N. Y.

4 Isotope Specialties Co., Burbank, Calif. drying in vacuo at $85^{\circ}$ for 24 hours. Samples were plated on aluminum planchets and assayed in a thin window gas flow proportional counter. The results are expressed as counts per minute per milliliter initial or final medium, or counts per minute per milliliter of tissue water. Fructose was determined by the method of Roe, Epstein, and Goldstein (20), 6-deoxyglucose by the method of Dische and Shettles (21), and galactose using "galactostat." 5 After incubation with $\alpha$-methylglucose, 3-O-methylglucose, and xylose, samples of initial medium and deproteinized tissue homogenate were chromatographed on paper in a butanol : pyridine: water $(6: 4: 3)$ system (22). To localize the $\mathrm{C}^{14}$ activity, the paper was cut into small segments, which were placed in scintillation vials containing $0.5 \mathrm{ml}$ of water to which was added $10 \mathrm{ml}$ of a solution of $125 \mathrm{~g}$ naphthalene, $7.5 \mathrm{~g}$ PPO (2,5-diphenyloxazole) and $0.375 \mathrm{~g}$ dimethyl POPOP [1,4-bis-2-(4-methyl-5-phenyloxazolyl) benzene] per liter of $p$-dioxane (23), and counted in a liquid scintillation spectrometer. $^{6} \mathrm{~A}$. single $\mathrm{C}^{14}$ peak, corresponding to the peak in the initial medium, was found for the samples from the tissue homogenate, indicating that intracellu-

5 Worthington Biochemical Corp., Freehold, N. J.

${ }^{6}$ Nuclear Chicago Corp., Chicago, Ill. 
lar accumulation of $\alpha$-methylglucose, 3-0-methylglucose, and xylose occurred without hydrolysis or other structural alteration.

Pathways and quantitation of fructose conversion to glucose. Segments of mucosa, weighing 0.6 to $2 \mathrm{~g}$ were incubated in $5 \mathrm{ml}$ of the Krebs-Ringer bicarbonate buffer, containing either $10 \mathrm{mg}$ or $15 \mathrm{mg}$ of unlabeled glucose and either $1 \mathrm{mg}$ or $3.5 \mathrm{mg}$ of fructose-1-C $\mathrm{C}^{14}$ or fructose-6-C $C^{14}$. In one experiment, no glucose was present. Incubation lasted 20 minutes to 75 minutes and was performed at $37^{\circ} \mathrm{C}$ with shaking under $95 \% \quad \mathrm{O}_{2}$ and $5 \%$ $\mathrm{CO}_{2}$. Variations in tissue weight and incubation time depended on the amount of available tissue, but were kept constant for each experiment.

Glucose and fructose uptakes, i.e., the difference between sugar content in initial and final media, were determined by incubating samples of media with and without glucose oxidase, followed by determination of reducing content by the Somogyi-Nelson procedure (19). The difference between total reducing content and nonglucose reducing content was the measure of true glucose. Fructose content was considered to equal the nonglucose reducing content. Fructose was also determined by the method of Roe and co-workers (20), and the two methods were in agreement. Disappearance of fructose- $\mathrm{C}^{14}$ was determined by making the fructosazones from samples of initial and final medium after treatment with glucose oxidase. These were plated on stainless steel planchets and assayed in a thin, end-window, gas-flow, proportional counter.

At the completion of incubation, tissue glycogen was isolated, purified, and hydrolyzed to glucose. Carrier glucose was added. A sample was combusted to $\mathrm{CO}_{2}$ for assay for $\mathrm{C}^{14}$. This allowed an estimate of the recovery of $\mathrm{C}^{14}$ in the subsequent degradation as well as a measure of the total incorporation of $\mathrm{C}^{14}$ into glycogen. The remainder of the glucose was degraded using Leuconostoc mesenteroides as previously described (24, 25). This procedure yields carbon 1 as $\mathrm{CO}_{2}$, carbons 2,3 as acetate via ethyl alcohol, and carbons $4,5,6$ as lactate; the acetate and lactate were combusted to $\mathrm{CO}_{2}$. Where indicated, all six carbons were isolated individually as $\mathrm{CO}_{2}(24,25)$.

To examine the glucose in the medium, deproteinization with $\mathrm{Ba}(\mathrm{OH})_{2}-\mathrm{ZnSO}_{4}$ was performed (19); the supernatant was purified by passage through a mixed bed column of Amberlite IR-120 7 in the $\mathrm{H}^{+}$form and Duolite A-4 ${ }^{8}$ in the $\mathrm{OH}-$ form, and the eluate was lyophilized. To remove radioactive fructose from the solution, two consecutive procedures were employed. The glucose and fructose were initially separated by descending paper chromatography on Whatman $3 \mathrm{MM}$ paper using an $n$-butanol: acetic acid: water solvent ( $4: 1: 5$ by volume) with fructose and glucose as guide spots (26). The spots were visualized by means of a periodate-permanganate spray. Good separation was obtained, and the area

${ }^{7}$ Rohm and Haas Co., Philadelphia, Pa.

8 Chemical Process Co., Redwood City, Calif. paralleling the glucose guide spots was eluted with water. The glucose was then oxidized to gluconic acid by incubation with $1 \mathrm{mg}$ of glucose oxidase (type III, $40,000 \mathrm{U}$ per $\mathrm{g})^{9}$ in $1 \mathrm{M}$ phosphate buffer $\mathrm{pH} 5.6$ under $\mathrm{O}_{2}$ with shaking at $37^{\circ} \mathrm{C}$ for $2 \frac{1}{2}$ hours. After incubation, the solution was deproteinized with $\mathrm{Ba}(\mathrm{OH})_{2-}$ $\mathrm{ZnSO}_{4}$, potassium gluconate was added as carrier, and the gluconate was separated from any residual fructose by passage through Dowex-1 10 in the $\mathrm{Cl}^{-}$form. This retained the gluconate, but not the fructose, when the column was thoroughly washed with water. Gluconate was eluted in fractions with $0.05 \mathrm{~N} \mathrm{HCl}$. Presence of gluconate in the various fractions was determined by oxidizing samples with periodic acid and testing for the presence of formaldehyde colorimetrically with chromotropic acid reagent (27). Fractions that contained gluconate were combined. A sample was combusted to $\mathrm{CO}_{2}$ to determine the adequacy of recovery of $\mathrm{C}^{14}$ in the subsequent degradation, as well as to measure the total incorporation of $\mathrm{C}^{\mathbf{1 4}}$ into glucose. Gluconate was degraded by oxidation with periodate (28) to yield carbon 1 as $\mathrm{CO}_{2}$, carbons $2,3,4,5$ as formic acid, and carbon 6 as formaldehyde. Formaldehyde was separated from formic acid by distillation and was oxidized to $\mathrm{CO}_{2}$ with potassium permanganate (29). Formic acid was steam distilled and oxidized to $\mathrm{CO}_{2}$ with mercuric acetate $(30)$.

$\mathrm{CO}_{2}$ obtained from the individual carbons of glucose and glycogen was evolved into ethanolamine and methyl cellosolve ( $1: 2$ by volume), which was dissolved in scintillation fluid consisting of toluene, methyl cellosolve, and ethanol (110:88:13 by volume), containing PPO, and the samples were counted in the liquid scintillation spectrometer (31).

The preparation of fructose- $6-C^{14}$ has been described previously (32). Fructose-1-C $C^{11}$ was treated with glucose oxidase and isolated after paper chromatography to assure removal of any glucose contaminant. To confirm the position of label, osazones of fructose-1- $C^{14}$ and $6-C^{14}$ were prepared, and their radioactivity was compared to that of the bis-phenylhydrazones of mesoxalaldehyde prepared by the method of Topper and Hastings (29). With fructose-1- $\mathrm{C}^{14}$, over $90 \%$ of the activity was recovered in the phenylhydrazone, containing carbons $1,2,3$ of glucose. With fructose- $6-C^{14}$, only $0.1 \%$ of the activity was in this fraction.

Incorporation of $C^{14}$ of $D$-glyceraldehyde-3-C $C^{14}$ into glucose. Further information was obtained regarding the fate of $\mathrm{D}$-glyceraldehyde in intestinal mucosa by incubating tissue with $1.6 \mathrm{mg}$ of $\mathrm{D}$-glyceraldehyde-3-C $\mathrm{C}^{\mathbf{1 4}}$ in the presence of 10 or $15 \mathrm{mg}$ of unlabeled glucose. The procedure was identical to that outlined above for fructose. The D-glyceraldehyde-3-C ${ }^{14}$ was prepared as previously described (32).

Pentose cycle estimation. The contribution of the pentose cycle to over-all glucose metabolism was estimated by the method of Katz and Wood $(33,34)$. Incubation of

\footnotetext{
9 Sigma Chemical Co., St. Louis, Mo.

10 Dow Chemical Co., Midland, Mich.

11 Purchased from Tracerlab, Inc., Boston, Mass.
} 


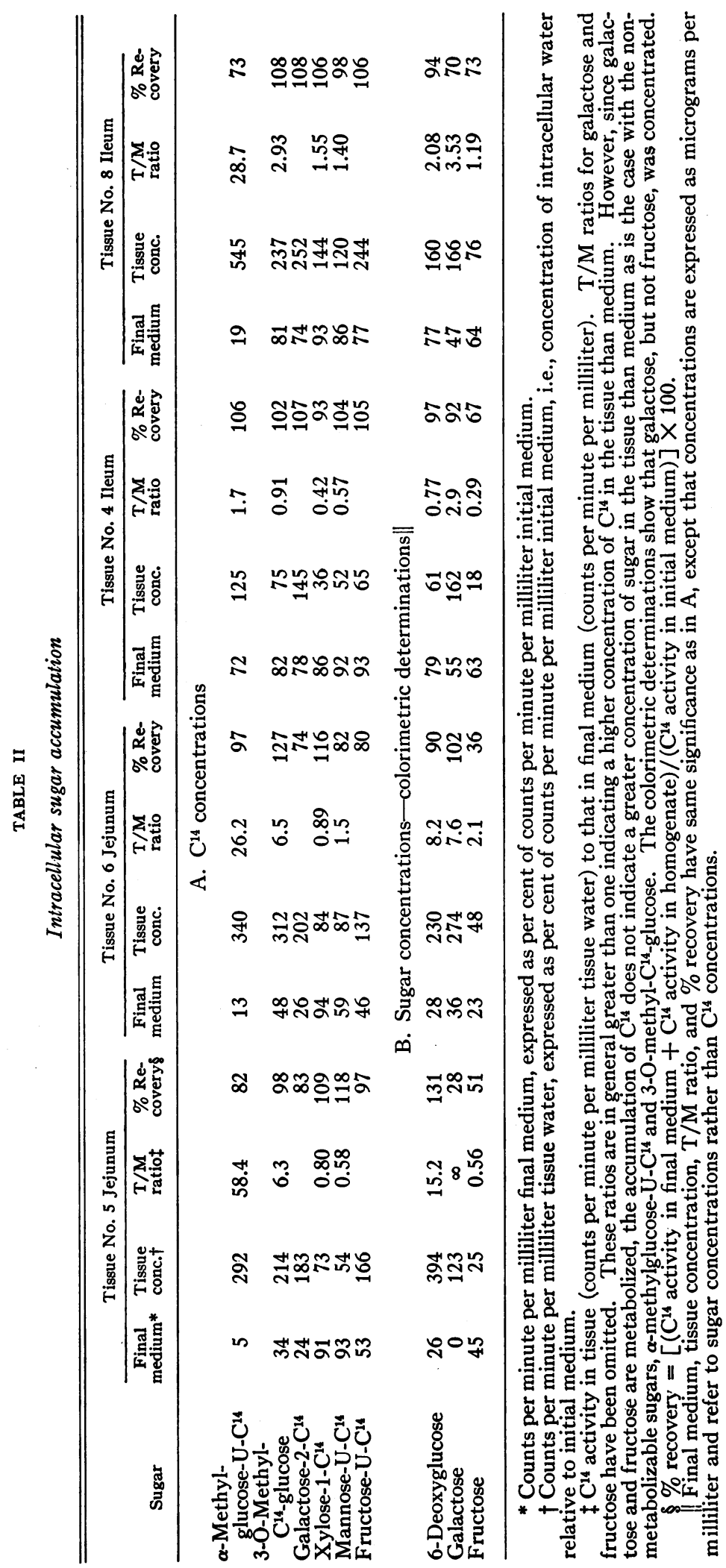


TABLE III

Distribution of $C^{14}$ in the glucose unit of glycogen from human intestinal mucosa incubated with fructose-1-C $C^{14}$ and $6-C^{14}$

\begin{tabular}{|c|c|c|c|c|c|c|}
\hline \multirow[b]{2}{*}{ Substrate } & \multirow[b]{2}{*}{ Tissue } & \multicolumn{4}{|c|}{ Specific activity* } & \multirow[b]{2}{*}{ Recovery } \\
\hline & & C-1 & C-2,3 & C-4,5,6 & C-6† & \\
\hline Fructose-1- $C^{14}$ & $\begin{array}{l}1 \S \\
2 \| \\
3 \pi \\
6 * *\end{array}$ & $\begin{array}{l}35.8 \\
24.4 \\
55.5 \\
37.1\end{array}$ & $\begin{array}{l}4.1 \\
5.9 \\
5.5 \\
6.3\end{array}$ & $\begin{array}{l}60.1 \\
69.7 \\
39.0 \\
56.6\end{array}$ & $\begin{array}{l}53.9 \\
56.1 \\
35.5 \\
48.4\end{array}$ & $\begin{array}{c}\% \\
103.8 \\
107.7 \\
94.4 \\
88.0\end{array}$ \\
\hline Fructose-6-C 14 & $\begin{array}{l}18 \\
2 \| \\
3 \pi\end{array}$ & $\begin{array}{l}26.2 \\
16.5 \\
32.2\end{array}$ & $\begin{array}{l}3.9 \\
5.3 \\
4.5\end{array}$ & $\begin{array}{l}69.9 \\
78.2 \\
63.3\end{array}$ & $\begin{array}{l}60.8 \\
59.2 \\
55.5\end{array}$ & $\begin{array}{r}103.7 \\
104.6 \\
94.9\end{array}$ \\
\hline
\end{tabular}
100.

* Relative specific activity in C-1, C-2,3, or C-4,5,6 with the sum of activities of $\mathrm{C}-1+\mathrm{C}-2,3+\mathrm{C}-4,5,6$ set equal to

† Specific activity in carbon 6 was obtained by calculation. There is very little $C^{14}$ in carbons 2 and 3 , and based on previous experience, carbons 4 and 5 should also contain minimal activity. Since carbons 1,2,3 and 4,5,6 remain intact in the formation of hexose from triose phosphate, $\mathrm{C}^{14}$ activity in carbon 1 to carbon 6 should be proportional to the $\mathrm{C}^{14}$ activity in carbons $1,2,3$ to that in carbons $4,5,6$ so that $\mathrm{C}-6=[\mathrm{C}-1(\mathrm{C}-4,5,6)] /[\mathrm{C}-1+\mathrm{C}-2,3]$. To verify the reliability of this calculation, lactate, representing C-4,5,6 of glycogen in tissue No. 3, with fructose-6-C $C^{14}$ as substrate, was degraded and each carbon was assayed individually. Relative activities in carbons 4,5, and 6 were 1.6, 0.8, and 60.9.

$\ddagger$ Recovery represents the sum of the activities of $\mathrm{C}-1+\mathrm{C}-3,2+\mathrm{C}-4,5,6$ obtained by degradation expressed as a per cent of the total activity in the intact glucose molecule as determined by combustion.

\& Tissue No. 1:2 g mucosa incubated 25 minutes with $10 \mathrm{mg}$ nonlabeled glucose and $1 \mathrm{mg} \mathrm{C} \mathrm{C}^{14}$-fructose.

II Tissue No. 2: $0.6 \mathrm{~g}$ mucosa incubated 75 minutes with $10 \mathrm{mg}$ nonlabeled glucose and $1 \mathrm{mg} \mathrm{C}^{14}$-fructose.

IT Tissue No. 3: $1.1 \mathrm{~g}$ mucosa incubated 20 minutes with $15 \mathrm{mg}$ nonlabeled glucose and $3.5 \mathrm{mg} \mathrm{C}^{14}$-fructose.

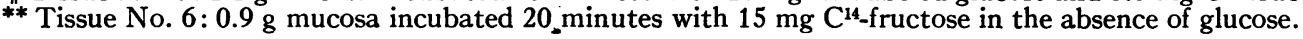

three tissues, weighing $0.89 \mathrm{~g}, 1.0 \mathrm{~g}$, and $0.35 \mathrm{~g}$, respectively, with $30 \mathrm{mg}$ of glucose-2-C $\mathrm{C}^{\mathbf{1 6}}, 1$ was performed for 45 minutes, and the degree of randomization of $C^{14}$ in glucose from glycogen was measured. The larger quantity of glucose was used in this experiment to approach steady state conditions throughout the incubation. Over $60 \%$ of the glucose remained at the end of incubation.

Enzyme studies. Fructokinase was assayed by the method of Ginsberg and Hers (11). A homogenate of intestinal mucosa was incubated with fructose in the presence and absence of glucose. The disappearance of fructose in the presence of ATP, as measured by the method of Roe and associates (20) on a $\mathrm{Ba}(\mathrm{OH})_{2-}$ $\mathrm{ZnSO}_{4}$ filtrate, was taken as evidence of phosphorylation. To determine whether the phosphorylation product was fructose-1-phosphate or fructose-6-phosphate, the fructose phosphate was isolated as a barium salt and tested for lability, i.e., the liberation of fructose by $1 \mathrm{~N}$ $\mathrm{HCl}$ at $100^{\circ} \mathrm{C}$. To measure the liberation, samples were neutralized, the remaining fructose phosphate was precipitated by $\mathrm{Ba}(\mathrm{OH})_{2}$ and $\mathrm{ZnSO}_{4}$ addition, and free fructose was determined.

Glucose-6-phosphatase activity was determined by measuring for 60 minutes over a $\mathrm{pH}$ range the hydrolysis of glucose-6-phosphate as compared to glucose-1phosphate by a microsomal fraction of intestinal mucosa (11). Parallel studies were performed on rat, hamster, and human intestinal mucosa. A control experiment, performed in the absence of mucosal homogenate, demonstrated no hydrolysis of glucose-6-phosphate or glucose-1phosphate at the various $\mathrm{pH}$ values.

\section{Results}

Sugar specificity. The studies of structural specificity with respect to accumulation of monosaccharides against a gradient are outlined in Table II. As measured by $\mathrm{C}^{\mathbf{1 4}}$, recovery was essentially complete; with colorimetric determinations, however, recovery was more variable. Tissue concentrations following incubation of jejunal mucosa with galactose and nonmetabolizable glucose derivatives, $\alpha$-methylglucose, 3-O-methylglucose and 6-deoxyglucose, were markedly higher than the initial medium concentration. At the completion of incubation, a definite concentration gradient for these sugars existed between medium and tissue (as indicated in Table II by the $\mathrm{T} / \mathrm{M}$ ratios). No definite $\mathrm{C}^{\mathbf{1 4}}$ concentration gradient was produced with xylose and mannose. An accumulation of $\mathrm{C}^{14}$ was observed in tissue with fructose as with galactose; colorimetrically, however, fructose was shown not to be concentrated, and the $\mathrm{C}^{14}$ accumulation is presumably attributable to metabolic products. Incubation with ileum (tissue no. 4) differed in that only galactose and $\alpha$-methylglucose were concentrated, and their gradients were less than that seen in the two experiments with jejunum. With ileum (tissue no. 
TABLE IV

\begin{tabular}{|c|c|c|c|c|c|}
\hline \multirow[b]{2}{*}{ Substrate } & \multirow[b]{2}{*}{ Tissue } & \multicolumn{3}{|c|}{ Specific activity } & \multirow[b]{2}{*}{ Recovery $\dagger$} \\
\hline & & $\mathrm{C}-1$ & $C-2,3,4,5$ & C-6 & \\
\hline & & & & & $\%$ \\
\hline \multirow[t]{2}{*}{ Fructose-1-C14 } & 1 & 47.1 & 8.0 & 44.9 & 81.4 \\
\hline & 2 & 36.6 & 7.4 & 56.0 & 70.4 \\
\hline Fructose-6-C14 & 1 & 30.4 & 4.9 & 64.7 & 95.4 \\
\hline
\end{tabular}

* Experiments of Table III

+ Recovery represents the sum of the activities of all six carbons obtained by degradation expressed as a per cent of the total activity in the intact glucose molecule as determined by combustion.

8) definite concentration gradients were found as with jejunum, but except for $\alpha$-methylglucose the gradients were less.

Incorporation of $C^{14}$ of fructose-1-C $C^{14}$ and $6-C^{14}$ into glycogen and glucose. The experiments with fructose-1- $\mathrm{C}^{14}$ and $6-\mathrm{C}^{14}$ outlined in Tables III and IV demonstrate the occurrence of marked randomization of $\mathrm{C}^{14}$ between carbons 1 and 6 in the glucose unit derived from tissue glycogen, as well as the glucose formed in the medium. In most tissues, incubation with fructose-1-C $\mathrm{C}^{\mathbf{1 4}}$ resulted in higher $\mathrm{C}^{14}$ activity in carbon 6 than 1 . This can be accounted for by metabolism via the transaldolase reactions that are discussed subsequently. The similar pattern in tissue glycogen and medium glucose is consistent with their derivation from a single pool of glucose-6-phosphate.

Incorporation of $C^{14}$ of $D$-glyceraldehyde-3-C ${ }^{14}$ into glucose. Most of the $\mathrm{C}^{\mathbf{1 4}}$ of $\mathrm{D}$-glyceraldehyde3-C ${ }^{14}$ (Table V) appeared in carbons 1 and 6 of the glucose unit of glycogen. Much more activity was in carbon 6 than 1 .
TABLE V

Distribution of $C^{14}$ in glucose unit of glycogen after incubation with glyceraldehyde-3-C $C^{14}$

\begin{tabular}{|c|c|c|c|c|c|c|c|}
\hline \multirow[b]{2}{*}{ Tissue } & \multicolumn{6}{|c|}{ Specific activity* } & \multirow[b]{2}{*}{ Recovery } \\
\hline & C-1 & C-2 & C-3 & C-4 & C-5 & $\mathrm{C}-6$ & \\
\hline & & & & & & & $\%$ \\
\hline $2 \dagger$ & 29.6 & \multicolumn{2}{|c|}{$-14.0 \ddagger-$} & $\longrightarrow$ & $56.48-$ & - & 88 \\
\hline $3 \|$ & 28.5 & 4.6 & 3.6 & 6.4 & 1.6 & 55.3 & 89 \\
\hline
\end{tabular}

* Relative specific activity in individual carbons with the sum of activities in all six carbons set equal to 100 .

$\dagger$ Tissue No. 2. $0.6 \mathrm{~g}$ mucosa incubated 75 minutes with $10 \mathrm{mg}$ glucose and $1.6 \mathrm{mg}$ glyceraldehyde-3-C $\mathrm{C}^{14}$.

Sum of activities in $\mathrm{C}-2+\mathrm{C}-3$.

Sum of activities in C-4 + C-5 + C-6.

II Tissue No. 3. $1.1 \mathrm{~g}$ mucosa incubated 20 minutes with $15 \mathrm{mg}$ glucose and $1.6 \mathrm{mg}$ glyceraldehyde-3-C $\mathrm{C}^{14}$.

Pentose cycle. $\mathrm{C}^{14}$ of glucose-2-C $\mathrm{C}^{14}$ was randomized into carbons 1 and 3 of the glucose from glycogen (Table VI). The ratios of the specific activities of the top 3 carbons in a hexose-6-phosphate derivative (in this case glycogen) may be used to calculate the $\%$ of over-all metabolism occurring via the pentose cycle (34). The data suggest a pentose cycle contribution of 5 to $10 \%$. A small percentage of the $\mathrm{C}^{14}$ activity was found in carbons 4, 5, and 6 .

Enzyme studies. The results of one assay for fructokinase are recorded in Table VII. Disappearance of fructose to the extent of $58 \%$ only occurred in the presence of ATP, presumptive evidence for phosphorylation. The presence of glucose did not inhibit the disappearance. The product of the reaction was identified as fructose-1-phosphate by testing its rate of hydrolysis in acid (Figure 2). Eighty per cent of the fructose in the phosphorylated product was liberated in 40 minutes. Under these conditions fructose-1-

TABLE VI

Distribution of $C^{14}$ in glucose unit of glycogen after incubation with glucose-2-C ${ }^{14}$

\begin{tabular}{|c|c|c|c|c|c|c|c|c|}
\hline \multirow[b]{2}{*}{ Tissue } & \multicolumn{6}{|c|}{ Specific activity* } & \multirow[b]{2}{*}{ Recovery } & \multirow{2}{*}{$\begin{array}{l}\text { Pentose } \\
\text { cycle† }\end{array}$} \\
\hline & C-1 & $\mathrm{C}-2$ & $\mathrm{C}-3$ & C-4 & C-5 & $\overline{C-6}$ & & \\
\hline $\begin{array}{l}3 \ddagger \\
6 \\
7\end{array}$ & $\begin{array}{r}13.4 \\
7.9 \\
8.0\end{array}$ & $\begin{array}{l}100 \\
100 \\
100\end{array}$ & $\begin{array}{r}10.3 \\
11.3 \\
6.2\end{array}$ & 1.7 & 10.7 & 1.3 & $\begin{array}{l}\% \\
64.3\end{array}$ & $\begin{array}{c}\% \\
9.6 \\
8.5 \\
5.5\end{array}$ \\
\hline
\end{tabular}

* Relative specific activity in individual carbons with the activity of carbon 2 set equal to 100 .

+ Calculations of pentose cycle are based on the ratio of $C^{14}$ in carbons $1: 2$ and carbons $3: 2$, as described by Katz and Wood (34). This assumes complete equilibration of hexose-6-phosphates, and is supported by the similar ratio in carbons $1: 2$ compared to 6:5 with tissue No. 3 (33). With tissue No. 7, however, the ratio of $C^{14}$ in carbons $6: 5$ is higher than in carbons 1:2, suggesting that fructose-6-phosphate and glucose-6-phosphate are not completely equilibrated. Calculation based on nonequilibration gives a contribution of $15 \%$ (33).

$\ddagger 0.89 \mathrm{~g}$ mucosa (tissue No. 3 ), $1.0 \mathrm{~g}$ mucosa (tissue No.6), or $0.35 \mathrm{~g}$ mucosa (tissue No. 7 ) incubated 45 minutes with $30 \mathrm{mg}$ glucose-2-C $\mathrm{C}^{14}$. 
TABLE VII

Fructokinase assay in human intestinal mucosa*

\begin{tabular}{ccc}
\hline $\begin{array}{c}\text { Glucose } \\
\text { present }\end{array}$ & ATP & $\begin{array}{c}\text { Fructose } \\
\text { disappearance }\end{array}$ \\
\hline$\mu M$ & & $\%$ \\
0 & 0 & 1.5 \\
4.4 & 0 & 3.1 \\
22 & 0 & 4.1 \\
0 & + & 57.7 \\
2.2 & + & 56.2 \\
4.4 & + & 57.7 \\
11 & + & 62.4 \\
22 & + & 55.2 \\
\hline
\end{tabular}

* Fructokinase was assayed by the method of Ginsberg and Hers (11). The reaction mixture contained $2.2 \mu$ moles fructose, $8 \mu$ moles $\mathrm{MgCl}_{2}, 900 \mu$ moles $\mathrm{KCl}, 20 \mu$ moles cacodylate buffer $\mathrm{pH} 7.0,100 \mu$ moles $\mathrm{KF}, 1 \mathrm{ml} 20 \%$ homogenate of intestinal mucosa in water (tissue No. 3), and 8 mmoles ATP when present, with a final volume of $2 \mathrm{ml}$. Incubation was for $\mathbf{4 0}$ minutes, followed by deproteinization and measurement of fructose remaining in the proteinfree filtrate.

phosphate is very labile as compared to fructose6-phosphate (35). In an assay of a second tissue, $45 \%$ of the fructose disappeared in the presence of ATP; the disappearance again was

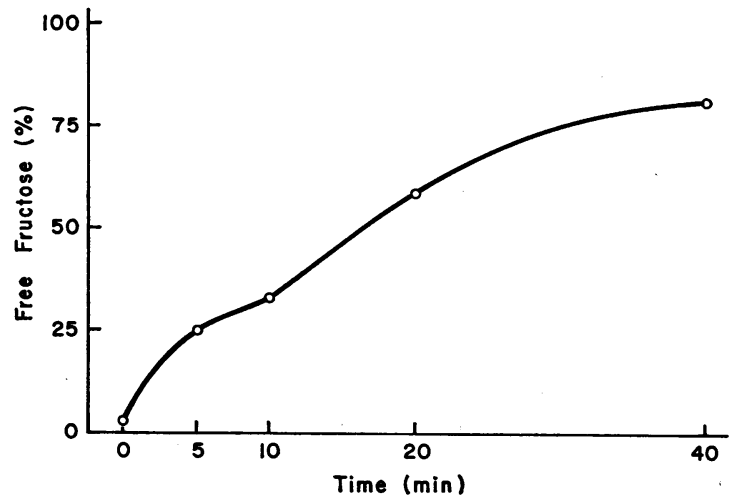

Fig. 2. LABILITY OF FRUCTOSE PHOSPHATE FORMED BY hoMOgENATES FROM HUMAN INTESTINAL MUCOSA. Fructose phosphate was prepared as outlined in Table VII, deproteinized with perchloric acid, filtered, neutralized with $\mathrm{KOH}$, and refiltered. Phosphate esters were precipitated by adding $25 \% \mathrm{BaCl}_{2}$ and 2 vol of ethanol. The precipitate was washed with $60 \%$ ethanol, dissolved in $1 \mathrm{~N} \mathrm{HCl}$, and placed in a water bath at $100^{\circ} \mathrm{C}$ (11). Samples were removed at the intervals shown, neutralized, treated with $\mathrm{Ba}(\mathrm{OH})_{2}$ and $\mathrm{ZnSO}_{4}$, and free fructose was determined in the supernatant by the method of Roe and associates (20). Total fructose was determined on a sample not treated with $\mathrm{Ba}(\mathrm{OH})_{2}$ and $\mathrm{ZnSO}_{4}$. Free fructose is plotted as a per cent of the total fructose.
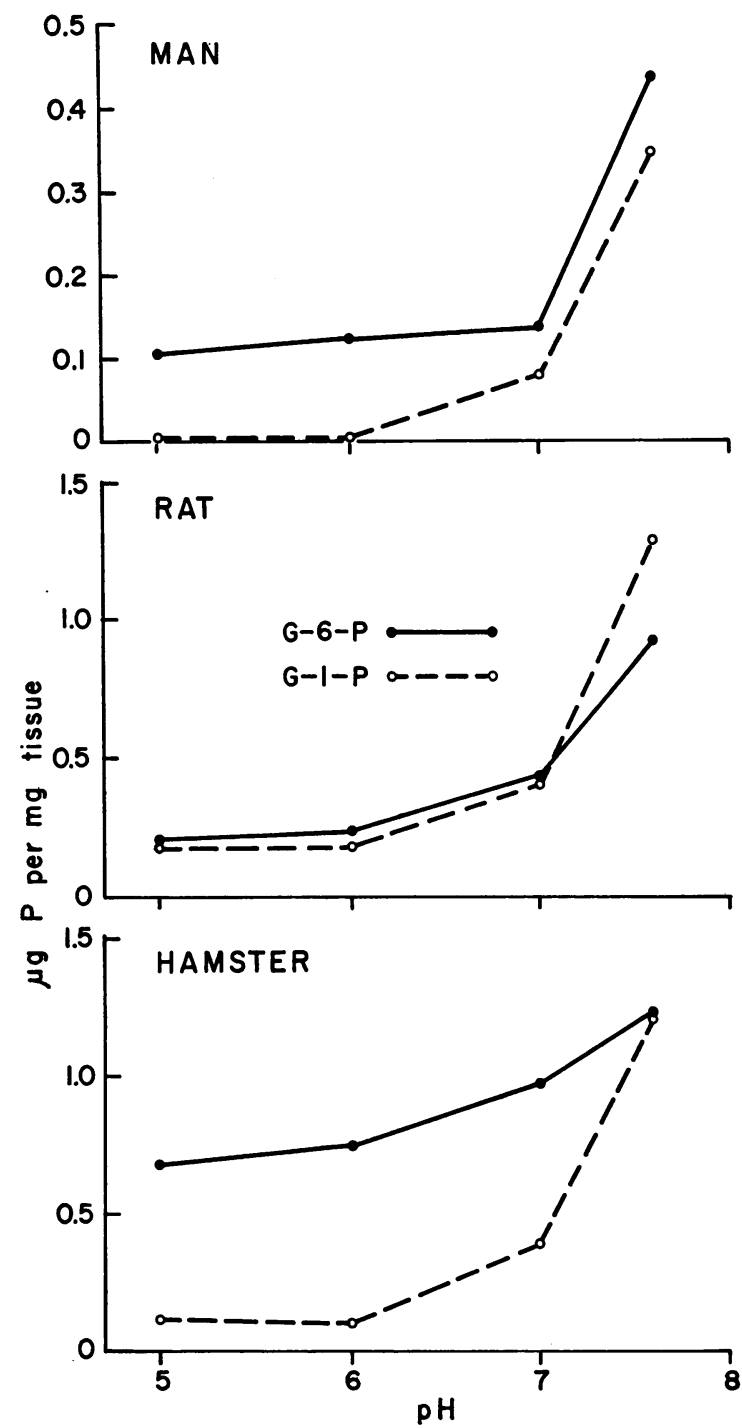

Fig. 3. Glucose-6-Phosphatase activity in A) man, B) RAT, AND C) HAMSTER INTESTinal mucosa. Mucosas were homogenized in cold $0.25 \mathrm{M}$ sucrose. A microsomal fraction was prepared by centrifuging the homogenates for 5 minutes at $25,000 \mathrm{rpm}$ and then centrifuging the supernatants at $38,000 \mathrm{rpm}$ for 30 minutes (11). Assay was essentially as described by Ginsberg and Hers (11) with activity determined by the release of free phosphorus from glucose-6-phosphate compared to glucose-1-phosphate.

unaffected by the presence of glucose. Acid hydrolysis was $75 \%$ at 40 minutes.

A microsomal fraction from human jejunal mucosa hydrolyzed glucose-6-phosphate at a rate considerably in excess of that of glucose-1-phosphate in the $\mathrm{pH}$ range of 5.0 to 7.6 (Figure $3 \mathrm{~A}$ ). At 
$\mathrm{pH}$ 6.0, which is the $\mathrm{pH}$ optimum for liver microsomes (11), $4.1 \mu$ moles of glucose-6-phosphate, as compared with $0.2 \mu$ moles of glucose-1-phosphate, was hydrolyzed per $\mathrm{g}$ of mucosa per 60 minutes. In a second jejunal tissue, $2.7 \mu$ moles of glucose-6-phosphate, compared with $0.4 \mu$ mole of glucose-1-phosphate, was hydrolyzed per $g$ of mucosa. Parallel assays of rat and hamster intestinal mucosa, presented in Figure $3 \mathrm{~B}$ and $3 \mathrm{C}$, confirmed the findings (11) that microsomes from rat intestinal mucosa hydrolyze glucose-6-phosphate and glucose-1-phosphate at the same rate, whereas microsomes from hamster intestinal mucosa hydrolyze glucose-6-phosphate more rapidly than glucose-1-phosphate in the range of $\mathrm{pH}$ 5 to 7.

\section{Discussion}

Sugar specificity. The mechanism of active transport of sugars by intestinal mucosa is unknown. Historical concepts regarding the transport mechanism, such as phosphorylation-dephosphorylation, or other chemical modifications, have not succeeded in accounting for the known phenomena. The current consensus favors adsorption to an unidentified membrane carrier on the luminal border of the cell membrane, and this interpretation is supported by kinetic data $(1,2)$. Movement across a layer of cells such as the intestinal epithelium (transcellular transport) is closely related to movement into and out of cells (transmembranous transport) (36). Thus, in the hamster (16), accumulation within cells accompanies transcellular transport against a gradient. Any tenable hypothesis regarding the mechanism of this transport must account for certain recently established facts. First, experiments with a variety of natural and synthetic sugars have shown that active transport has molecular specificity, i.e., the transported molecule has certain minimal structural requirements $(1,2,17)$. Secondly, studies on sugars known to be actively transported have demonstrated mutual inhibition, indicating competition for a common pathway (18). These features are analogous to the specificity and competitive inhibition of enzyme action by different substrates and suggest that sugars which are actively transported share a common carrier $(1,2)$.

The specificity of sugar transport by human intestinal mucosa (Table II) parallels data for hamster intestine $(1,2,17)$. Pentoses, or sugars lacking a hydroxyl group of the glucose configuration in position 2 , are not concentrated against a gradient. However, there is recent evidence that D-xylose will move against a gradient, if a counterflow with glucose is induced in the opposite direction (37), suggesting the facilitation of diffusion by mediation of a carrier shared with glucose. More recently, Cśaky and Lassen (38), by using a very small initial concentration of $D$-xylose, demonstrated uphill transport with a higher flux from lumen to serosa than the reverse. In keeping with data reported in other species $(18,39)$, 6-deoxyglucose is concentrated against a gradient by human intestinal mucosa, suggesting that in man, as well as in other species, active transport does not involve phosphorylation of glucose in the 6 position.

Pathways of fructose conversion to glucose. As noted in the introduction (see Figure 1), the conversion of fructose to glucose can occur by two major pathways. The first involves phosphorylation of fructose in the 6 position, with subsequent isomerization to glucose-6-phosphate, and hydrolysis to free glucose. When tested with specifically labeled fructose, conversion to glucose by this pathway should not result in randomization of the label. ${ }^{12}$ The second is via fructose-1phosphate, cleavage of the ester to triose phosphates, and condensation to fructose-1,6-diphosphate. By this pathway, $\mathrm{C}^{14}$ would be randomized during conversion to glucose, as a result of isotopic equilibration of triose phosphates.

\footnotetext{
12 Isolation of glucose-1,6-C $C^{14}$, after incubation with either fructose-1- $C^{14}$ or fructose-6-C $C^{14}$, but not glucose-1$\mathrm{C}^{14}$ or glucose-6- $\mathrm{C}^{14}$, indicates metabolism via fructose-1phosphate rather than fructose-6-phosphate (40). A major assumption required for this conclusion is that the phosphohexose isomerase catalyzed reaction is relatively rapid. If the conversion of fructose-6-phosphate to dihydroxyacetone phosphate and glyceraldehyde phosphate, their equilibration, and reconversion to fructose-6phosphate were rapid relative to the action of phosphohexose isomerase, fructose-6-P-1,6- $\mathrm{C}^{14}$ would be formed after the phosphorylation in the 6 position of fructose-1$\mathrm{C}^{14}$ or fructose-6-C $\mathrm{C}^{14}$. This is considered unlikely in intestine because of $a$ ) the relatively high activity of phosphohexose isomerase in tissues in which it has been assayed (41) and $b$ ) the large percentage of fructose-1phosphate in the barium precipitate demonstrable after incubation with fructose.
} 
Isolation of glucose-1,6-C $\mathrm{C}^{14}$ (Tables III and IV), after incubation with fructose-1-C $\mathrm{C}^{14}$ or fructose-6- $\mathrm{C}^{14}$, indicates that the second pathway exists in human intestinal mucosa. The degree of randomization between carbon 1 and carbon 6 , similar to results reported for guinea pig intestine (11), indicates that triose phosphate isomerase is active. The possibility that the first pathway also operates to some extent cannot be excluded by this study, but its presence would not be necessary to account for the data. The demonstration that fructose-1-phosphate is at least the major fraction of the fructose phosphate formed (Figure 2) supports the conclusion that the major proportion of fructose metabolism is via phosphorylation to fructose-1-phosphate. Sols has shown that fructose is phosphorylated to fructose-6-phosphate by hexokinase at a high rate in rat intestinal mucosa, but that this reaction is strongly inhibited in the presence of glucose (42). It might be expected that fructose would preferentially be phosphorylated via hexokinase in human intestine in the absence of glucose, whereas in the presence of glucose (for which hexokinase has a higher affinity), fructose would preferentially follow the pathway via fructokinase. However, the labeling pattern obtained with fructose-1-C $\mathrm{C}^{\mathbf{1 4}}$ in the one experiment performed in the absence of glucose ( Table III, tissue no. 6) was similar to that observed in the presence of glucose. This suggests either that hexokinase of the human intestine does not phosphorylate fructose preferentially in the absence of glucose to an extent sufficient to alter the pattern, or that endogenous glucose present in the tissue was sufficient to compete successfully with fructose for the hexokinase.

Attempts have been made to quantitate the conversion of fructose to glucose in man and in other species. In their patient, Miller and associates (9) estimated a conversion of fructose to glucose of $18 \%$ during transfer through the cell wall. Kiyasu and Chaikoff (4) collected mesenteric vein blood from jejunal loops of guinea pig intestine, after administering labeled fructose, and found a $70 \%$ conversion to glucose. However, in the rat, only about $10 \%$ of the absorbed fructose was recovered as glucose, possibly due to the absence of glucose-6-phosphatase. Recently, Shoemaker, Yanof, Turk, and Wilson (8) found, in the triply cannulated dog fed fructose, that $42 \%$ of the fructose was absorbed unchanged, whereas $58 \%$ was converted to glucose. For tissues no. 2 and no. 6,14 to $16 \%$ of the $\mathrm{C}^{14}$ of the fructose utilized was incorporated into glucose present in the final medium and 2 to $10 \%$ was incorporated into tissue glycogen. Since glucose is utilized continuously during the incubation, this represents a minimal value. In tissue no. 2 , with only 0.2 $\mathrm{mg}$ per $\mathrm{ml}$ fructose present in the medium, 0.57 $\mathrm{mg}$ per $\mathrm{g}$ tissue was taken up in 75 minutes. In tissue no. 6, with $1 \mathrm{mg}$ per $\mathrm{ml}$ fructose present, disappearance was $1.12 \mathrm{mg}$ per $\mathrm{g}$ in 20 minutes. Although a significant per cent of the fructose carbon utilized can be converted to glucose carbon, the equating of incorporation with net synthesis is not possible (43). As will be shown subsequently, there is good evidence that transaldolase reactions are partially responsible for the incorporation observed in these experiments.

Contribution of the pentose cycle. The presence of the pentose cycle has been established in hamster intestine by the greater $\mathrm{C}^{14} \mathrm{O}_{2}$ production from glucose-1-C $C^{14}$ than glucose-6-C $\mathrm{C}^{14}(44)$. The present report (Table VI) gives a quantitative measure of the presence of the pentose cycle in human intestinal mucosa.

Participation of the transaldolase reactions. Introduction via the Embden-Meyerhof pathway of $\mathrm{C}^{14}$ from fructose-1-C ${ }^{14}$ into carbon 6 of glucose necessitates a cleavage to triose phosphates, isotopic equilibration, and condensation to form glucose-6-phosphate. If there is failure to achieve isotopic equilibration of the triose phosphates, there will be unequal labeling of the top and bottom halves of the glucose molecule with greater activity in carbon 1 than carbon 6 . As the rate of isomerization of triose phosphates becomes more rapid, the $C^{14}$ activity in carbon 1 and carbon 6 will approach each other, but the activity of carbon 6 cannot be greater than that of carbon 1 . Therefore, in three experiments with fructose-1- $\mathrm{C}^{14}$ (Table III), the finding that 55 to $70 \%$ of the $\mathrm{C}^{14}$ was in the bottom half of the molecule requires another mechanism.

In the nonoxidative portion of the pentose cycle, a series of group transfers, catalyzed by transaldolase and transketolase, results in the conversion of three molecules of pentose-5-phosphate to two 
molecules of fructose-6-phosphate and one molecule of glyceraldehyde-3-phosphate. One of the intermediate reactions catalyzed by transaldolase is the transfer of a dihydroxyacetone moiety from sedoheptulose-7-phosphate to glyceraldehyde-3phosphate to form fructose-6-phosphate:

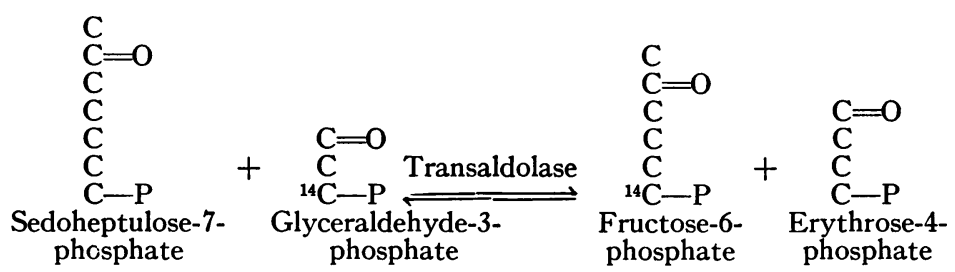

If fructose-1-phosphate-1- $\mathrm{C}^{14}$ is converted to triose phosphates, which then undergo isotopic equilibration, the glyceraldehyde-3-phosphate-3-C ${ }^{14}$ will equilibrate with the glyceraldehyde-3-phosphate pool derived from pentose cycle intermediates (provided there is a single pool of glyceraldehyde3 -phosphate). The glyceraldehyde-3-phosphate$3-\mathrm{C}^{14}$ can then be incorporated into fructose-6phosphate, with $\mathrm{C}^{\mathbf{1 4}}$ exclusively in the 6 position. The transaldolase reaction occurs in intestinal mucosa, since it is a part of the pentose cycle, and the randomization of glucose-2-C ${ }^{14}$ indicates that the cycle is present in the intestine. By this mechanism, $\mathrm{C}^{14}$ is incorporated only into carbon 6 , regardless of whether the initial substrate is fructose-1-C $\mathrm{C}^{14}$ or fructose-6- $\mathrm{C}^{\mathbf{1 4}}$. Consequently the finding of a significant quantity of activity in position 1 after incubation with fructose- $6-\mathrm{C}^{\mathbf{1 4}}$ indicates that the condensation of triose phosphates via the Embden-Meyerhof pathway must also occur.

An additional mechanism for the incorporation of $\mathrm{C}^{14}$ from fructose-1-C $\mathrm{C}^{14}$ into carbon 6 of glucose is by means of a transaldolase exchange reaction, between labeled glyceraldehyde-3-phosphate from fructose-1-phosphate-1- $\mathrm{C}^{14}$, and unlabeled and carbon 1-labeled fructose-6-phosphate (45):

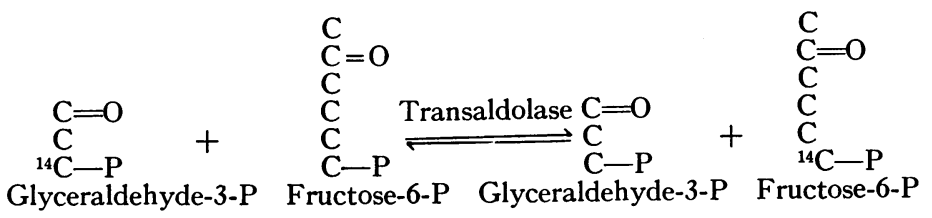

The unlabeled fructose-6-P participating in the reaction could arise from sources such as glycogen present in the tissue at the beginning of incubation and the fructose-6-P-1-C ${ }^{14}$ from triose phosphates via aldolase condensation and possibly by phosphorylation of fructose-1-C ${ }^{14}$ via hexokinase. The unlabeled glyceraldehyde-3-phosphate formed would be expected to enter the glyceraldehyde-3phosphate pool and be equilibrated at least partially with dihydroxyacetone- $P$, as evidenced by the formation of glucose-1,6- $\mathrm{C}^{\mathbf{1 4}}$ after incubation with fructose-6-C $\mathrm{C}^{\mathbf{1 4}}$. Although the transaldolase exchange reaction results in the incorporation of label into position 6 of glucose, it does not result in a net synthesis of glucose. Incorporation can also occur after reversal of the reactions of the pentose cycle involving transaldolase and transketolase (46).

Conversion of D-glyceraldehyde-3-C $C^{14}$ to glucose. The initial metabolism of D-glyceraldehyde, when presented to the cell, may differ from that of D-glyceraldehyde derived from fructose by cell metabolism (32). D-Glyceraldehyde may enter the Embden-Meyerhof scheme by formation of D-glyceraldehyde phosphate. If tested with D-glyceraldehyde-3-C $\mathrm{C}^{14}$, this would give rise to hexose$1,6-\mathrm{C}^{14}$, via condensation of triose phosphates, and hexose-6- $\mathrm{C}^{14}$ via the transaldolase reactions. D-Glyceraldehyde may also be reduced to glycerol with subsequent conversion to dihydroxyacetone phosphate to yield hexose-3,4-C ${ }^{14}$. In human intestinal mucosa, the finding of $83.8 \%$ of the $\mathrm{C}^{14}$ 
in carbons 1 and 6 (Table V) indicates that metabolism is primarily by conversion to D-glyceraldehyde-3-phosphate. The much greater incorporation of $\mathrm{C}^{14}$ into carbon 6 than carbon 1 indicates either hexose formation by condensation of triose phosphates with incomplete isotopic equilibration or a contribution by transaldolase-transketolase reactions.

Enzyme studies. The conversion of fructose to glucose via fructose-1-phosphate requires the presence of fructokinase and glucose-6-phosphatase, known to have a limited tissue distribution, as well as the more ubiquitous enzymes of the Embden-Meyerhof pathway. The action of fructokinase has been differentiated from that of hexokinase by the effect of glucose on the uptake of fructose (47). The demonstration of a phosphorylated product having the hydrolysis properties of fructose-1-phosphate, and the failure of glucose to inhibit its formation, as well as the labeling pattern found in glycogen, indicate the action of fructokinase.

Glucose-6-phosphatase is required as the final step in the conversion of fructose to glucose, and the absence of this enzyme (11) presumably accounts for the failure of rat intestine to convert fructose to glucose (Figure 3B). Ginsberg and Hers (11) compared the phosphatase activity of microsomes from the intestines of several species with respect to hydrolysis of glucose-6-phosphate and glucose-1-phosphate. In guinea pigs and rabbits, a peak of glucose-6-phosphatase activity occurs at $\mathrm{pH}$ 6.0. They found, and we have confirmed, that no peak occurs for hamster intestine at $\mathrm{pH} 6.0$ (Figure 3C). However, hydrolysis of glucose-6-phosphate proceeds 3 to 6 times more rapidly than that of glucose-1-phosphate in the $\mathrm{pH}$ range of 5.0 to 7.0. In the case of human intestinal mucosa, Ginsberg and Hers state that no evidence for a glucose-6-phosphatase peak at $\mathrm{pH} 6.0$ could be obtained, and they question the conversion of fructose to glucose by human intestinal mucosa on this basis. Although our findings corroborate the absence of a peak at $\mathrm{pH} 6.0$, they also show that hydrolysis of glucose-6-phosphate occurs at 6 to 20 times the rate of glucose1-phosphate at $\mathrm{pH} 6.0$, similar to the findings in the hamster, and indicating the presence of glucose-6-phosphatase activity in human intestinal mucosa. Öckerman found that fractionated hu- man intestinal mucosa was able to hydrolyze glucose-6-phosphate at $\mathrm{pH} 6.0$, but the specificity of the hydrolysis as compared to other phosphates was not established (14). Field, Epstein, and Egan recently demonstrated glucose-6-phosphatase activity in human intestine biopsy samples at $\mathrm{pH}$ 6.5 after correction for nonspecific phosphatases as measured with glycerol phosphate (15).

\section{Summary}

Sugar transport and fructose metabolism have been studied in specimens of human intestinal mucosa removed at surgery, and the following has been found: 1) Transport of sugars in man conforms to structural requirements in the hamster; some sugars are transported actively as shown by intracellular accumulation, whereas other sugars, such as fructose, are not. 2) Fructose is converted to glucose as measured by incorporation of $\mathrm{C}^{14}$ from fructose-1- $\mathrm{C}^{14}$ and fructose-6-C $\mathrm{C}^{14}$ into glucose and glycogen. 3) Initial metabolism of fructose is primarily via fructose-1-phosphate, as evidenced by the labeling pattern obtained with fructose-1- $\mathrm{C}^{14}$ and fructose- $6-\mathrm{C}^{14}$ and by the hydrolysis characteristic of the phosphate formed from fructose. 4) Glucose-6-phosphatase activity is present, as evidenced by the preferential hydrolysis of glucose-6-phosphate over glucose-1phosphate at acid $\mathrm{pH}$. 5) The pentose cycle is active in human intestine, as measured by randomization of glucose-2-C $\mathrm{C}^{14}$; the transaldolase catalyzed reactions, which are associated with the cycle, play a part in the incorporation of $\mathrm{C}^{14}$ from fructose- $\mathrm{C}^{14}$ into glucose. 6) Glyceraldehyde is initially metabolized via glyceraldehyde-3-phosphate, as determined by the labeling pattern obtained with glyceraldehyde-3-C ${ }^{14}$.

\section{Acknowledgments}

We were fortunate to have the expert technical assistance of Mr. Hollis R. Williams. We thank the members of the Department of Surgery, Western Reserve University, for assistance in obtaining the samples of intestine.

\section{References}

1. Crane, R. K. Intestinal absorption of sugars. Physiol. Rev. 1960, 40, 789.

2. Wilson, T. H. Intestinal Absorption. Philadelphia, W. B. Saunders, 1962, p. 69. 
3. Cori, C. F. The fate of sugar in the animal body. I. The rate of absorption of hexoses and pentoses from the intestinal tract. J. biol. Chem. 1925, 66, 691.

4. Kiyasu, J. Y., and I. L. Chaikoff. On the manner of transport of absorbed fructose. J. biol. Chem. 1957, 224, 935.

5. Bollman, J. L., and F. C. Mann. The physiology of the liver. XIX. The utilization of fructose following complete removal of the liver. Amer. J. Physiol. 1963, 96, 683.

6. Darlington, W. A., and J. H. Quastel. Absorption of sugars from isolated surviving intestine. Arch. Biochem. 1953, 43, 194.

7. Wilson, T. H., and T. N. Vincent. Absorption of sugars in vitro by the intestine of the golden hamster. J. biol. Chem. 1955, 216, 851.

8. Shoemaker, W. C., H. M. Yanof, L. N. Turk, and T. H. Wilson. Glucose and fructose absorption in the unanesthetized dog. Gastroenterology 1963, 44, 654 .

9. Miller, M., J. W. Craig, W. R. Drucker, and H. Woodward, Jr. The metabolism of fructose in man. Yale J. Biol. Med. 1956, 29, 335.

10. Kjerulf-Jensen, $K$. The hexosemonophosphoric acids formed within the intestinal mucosa during absorption of fructose, glucose and galactose. Acta physiol. scand. 1942, 4, 225.

11. Ginsberg, V., and H. G. Hers. On the conversion of fructose to glucose by guinea pig intestine. Biochim. biophys. Acta (Amst.) 1960, 38, 427.

12. Salomon, L. L., and J. E. Johnson. Transfer of fructose and glucose across surviving guinea pig intestine. Arch. Biochem. 1959, 82, 179.

13. James, J., and L. L. Salomon. Intestinal glucose-6phosphatase. Fed. Proc. 1964, 23, 533.

14. Öckerman, P. A. Glucose-6-phosphatase in human jejunal mucosa. Lack of activity in glycogenesis of Cori's type I. Clin. chim. Acta 1964, 9, 151.

15. Field, J. B., S. M. Epstein, and T. Egan. Intestinal glucose-6-phosphatase in patients with von Gierke's disease and their relatives (abstract). Program of the Forty-sixth Meeting of the Endocrine Society, June 1964, p. 56.

16. Crane, R. K., and P. Mandelstam. The active transport of sugars by various preparations of hamster intestine. Biochim. biophys. Acta (Amst.) 1960, $45,460$.

17. Landau, B. R., L. Bernstein, and T. H. Wilson. Hexose transport by hamster intestine in vitro. Amer. J. Physiol. 1962, 203, 237.

18. Jorgensen, C. R., B. R. Landau, and T. H. Wilson. A common pathway for sugar transport in hamster intestine. Amer. J. Physiol. 1961, 200, 111.

19. Somogyi, M. Notes on sugar determination. J. biol. Chem. 1952, 195, 19.

20. Roe, J. H., J. H. Epstein, and N. P. Goldstein. A photometric method for the determination of inu- lin in plasma and urine. J. biol. Chem. 1949, 178, 839.

21. Dische, Z., and L. B. Shettles. A specific color reaction of methylpentoses and a spectrophotometric micromethod for their determination. J. biol. Chem. 1948, 175, 595.

22. Jeanes, A., C. S. Wise, and R. J. Dimler. Improved techniques in paper chromatography of carbohydrates. Analyt. Chem. 1951, 23, 415.

23. Werbin, H., I. L. Chaikoff, and M. R. Imada. Rapid sensitive method for determining $\mathrm{H}^{3}$-water in body fluids by liquid scintillation spectrometry. Proc. Soc. exp. Biol. (N. Y.) 1959, 102, 8.

24. Merlevede, W., G. Weaver, and B. R. Landau. Effects of thyrotropic hormone on carbohydrate metabolism in thyroid slices. J. clin. Invest. 1963, 42, 1160.

25. Sakami, W., Ed. Degradation of glycogen in Handbook of Isotope Tracer Methods. Cleveland, Western Reserve University, 1955, p. 27.

26. Partridge, S. M. Filter-paper partition chromatography of sugars. I. General description and application to the qualitative analysis of sugars in apple juice, egg white, and foetal blood of sheep. Biochem. J., 1948, 42, 238.

27. Burton, R. M. The determination of glycerol and dihydroxyacetone in Methods in Enzymology, S. P. Colowick and N. O. Kaplan, Eds. New York, Academic Press, 1957, vol. 3, p. 246.

28. Eisenberg, F., Jr. Degradation of isotopicallylabeled glucose via periodate oxidation of gluconate. J. Amer. chem. Soc. 1954, 76, 5152.

29. Topper, Y. J., and A. B. Hastings. A study of the chemical origins of glycogen by use of $\mathrm{C}^{\mathbf{1 4}}$-labeled carbon dioxide, acetate, and pyruvate. J. biol. Chem. 1949, 179, 1255.

30. Pirie, N. W. The manometric determination of formic acid. Biochem. J. 1946, 40, 100.

31. Kornblatt, J. A., P. Bernath, and J. Katz. The determination of specific activity of $\mathrm{BaC}^{14} \mathrm{O}_{3}$ by liquid scintillation assay. Int. J. appl. Radiat. 1964, 15, 191.

32. Landau, B. R., and W. Merlevede. Initial reactions in the metabolism of $\mathrm{D}$ - and L-glyceraldehyde by rat liver. J. biol. Chem. 1963, 238, 861.

33. Landau, B. R., G. E. Bartsch, J. Katz, and H. G. Wood. Estimation of pathway contributions to glucose metabolism and of the rate of isomerization of hexose-6-phosphate. J. biol. Chem. 1964, 239, 686.

34. Katz, J., and H. G. Wood. The use of glucose-C ${ }^{14}$ for the evaluation of the pathways of glucose metabolism. J. biol. Chem. 1960, 235, 2165.

35. Cori, G. T., S. Ochoa, M. W. Slein, and C. F. Cori. The metabolism of fructose in liver. Isolation of fructose-1-phosphate and inorganic pyrophosphate. Biochim. biophys. Acta (Amst.) 1951, 7, 304.

36. Wilbrandt, W., and T. Rosenberg. The concept of 
carrier transport and its corollaries in pharmacology. Pharmacol. Rev. 1961, 13, 109.

37. Salomon, L. L., J. A. Allums, and D. E. Smith. Possible carrier mechanism for the intestinal transport of D-xylose. Biochem. biophys. Res. Commun. 1961, 4, 123.

38. Cśaky, T. Z., and U. V. Lassen. Active intestinal transport of D-xylose. Biochim. biophys. Acta (Amst.) 1964, 82, 215.

39. Crane, R. K. Studies on the mechanism of the intestinal absorption of sugars. III. Mutual inhibition, in vitro, between some actively transported sugars. Biochim. biophys. Acta (Amst.) 1960, 45, 477.

40. Hers, H. G. The conversion of fructose-1-C $\mathrm{C}^{14}$ and sorbitol-1-C $\mathrm{C}^{14}$ to liver and muscle glycogen in the rat. J. biol. Chem. 1955, 214, 373.

41. Shonk, C. E., B. J. Koven, H. Majima, and G. E. Boxer. Enzyme patterns in human tissues. II. Glycolytic enzyme patterns in nonmalignant human tissues. Cancer Res. 1964, 24, 722.
42. Sols, A. The hexokinase activity of the intestinal mucosa. Biochim. biophys. Acta (Amst.) 1956, 19, 144.

43. Landau, B. R. Gluconeogenesis and pyruvate metabolism in rat kidney, in vitro. Endocrinology 1960, 67, 744.

44. Landau, B. R., and T. H. Wilson. The role of phosphorylation in glucose absorption from the intestine of the golden hamster. J. biol. Chem. 1959, 234, 749.

45. Ljungdahl, L., H. G. Wood, E. Racker, and D. Couri. Formation of unequally labeled fructose-6phosphate by an exchange reaction catalyzed by transaldolase. J. biol. Chem. 1961, 236, 1622.

46. Landau, B. R., and J. Katz. A quantitative estimation of the pathways of glucose distribution in rat adipose tissue in vitro. J. biol. Chem. 1964, 239, 697.

47. Slein, M. W., G. T. Cori, and C. F. Cori. A comparative study of hexokinase from yeast and animal tissues. J. biol. Chem. 1950, 186, 763. 